\title{
CYTOMEGALOVIRAL COLITIS IN HIV POSITIVE PATIENTS: endoscopic findings
}

\author{
Oswaldo MARQUES Jr, Marcelo AVERBACH, Esdras Camargo Andrade ZANONI, \\ Paulo Alberto Falco Pires CORRÊA, José Luiz PACCOS and Raul CUTAIT
}

\begin{abstract}
Background - Diarrhea in seropositive human immunodeficiency virus patients is one of the most important and disabling symptoms, and often decreases their quality of life. Cytomegalovirus colitis is among the principal causes of this symptom and colonoscopy is the gold standard examination to diagnose it. Aim - To define the main endoscopic findings in seropositive human immunodeficiency virus patients with cytomegalovirus colitis. Methods - Two hundred and forty-three colonoscopies were performed in 200 seropositive human immunodeficiency virus patients with diarrhea associated or not to abdominal pain or gastrointestinal bleeding, over 10-year period, whom 51 patients were diagnosed with cytomegalovirus colitis. Full length colonoscopy with ileum intubation was always tried and multiple biopsies of all segments examined, including endoscopically normal segments, were attempted. All diagnoses were confirmed by histologic and immunohistochemical studies. Results - Total colonoscopy was possible in $98.03 \%$ and ileum intubation in $88.23 \%$ of these cytomegalovirus colitis patients. At colonoscopy, a heterogeneous ulcerative pattern was presented in $72.54 \%$, an inflammatory process of the mucosa in $21.56 \%$ and $5.88 \%$ of the patients mucosa was endoscopically normal. Conclusion - Full length colonoscopy with ileum intubation and multiples biopsies of all segments, even when they are endoscopically normal, have always to be attempted in cases of seropositive human immunodeficiency virus patient with diarrhea.
\end{abstract}

HEADINGS - Acquired immunodeficiency syndrome. Colitis. Cytomegalovirus infections. Diarrhea. Colonoscopy.

\section{INTRODUCTION}

Two thirds of seropositive human immunodeficiency virus $\left(\mathrm{HIV}^{+}\right)$patients develop an unexplained diarrhea sometime during the course of their illness ${ }^{(10,20,32,37)}$. Infectious etiologies account for $30 \%$ to $80 \%$ of the diarrhea and the chance for detecting an infectious agent depends on patient characteristics and effectiveness of endoscopic of evaluation ${ }^{(26,31,33,37)}$.

In acquired immunodeficiency syndrome (AIDS) patients with cytomegaloviral (CMV) disease, an infection of the lower gastrointestinal tract occurs most commonly ${ }^{(36)}$. Over $60 \%$ of patients with AIDS have serologic evidence of latent $\mathrm{CMV}$ infection. CMV is the most common colonic pathogen in $\mathrm{HIV}^{+}$patients causing $5 \%$ to $10 \%$ of their colitis ${ }^{(17)}$ and can be one of the pathogens in $45 \%$ of patients with severe diarrhea ${ }^{(33)}$.

Colitis due to CMV usually occurs in $\mathrm{HIV}^{+}$patients with CD4 lymphocyte counts $<100$ cells $/ \mathrm{mm}^{3}$ and has a myriad of presenting symptoms ${ }^{(3,5)}$. Patients more commonly have diarrhea, but can present abdominal pain, fever and loss of weight ${ }^{(21,39)}$. Life-threatening complications may also occur, including massive lower gastrointestinal bleeding ${ }^{(4,9)}$, colonic perforation ${ }^{(25}{ }^{34)}$, acute appendicitis ${ }^{(15)}$, ileocecal obstruction $^{(40)}$ and toxic megacolon ${ }^{(1)}$.

Cytomegalovirus colitis (CMVC) is a cause of considerable morbidity and mortality, with previous studies reporting a median survival time from 18 to 71 weeks $\mathbf{s}^{(6,7,16,19,23,38)}$ and recurrence is observed in $36 \%-75 \%$ of patients ${ }^{(6,7,23)}$.

Specific treatment according to the results of endoscopy may improve survival in these patients ${ }^{(37)}$. Endoscopic patterns of $\mathrm{CMVC}$ in $\mathrm{HIV}^{+}$patients are heterogeneous, although subepithelial hemorrhage, colitis and/or ulcers can be typical. Its appearance could mimic ulcerative colitis, Crohn's disease and pseudomembranous colitis ${ }^{22,29,30)}$

The aim of this report is to present our experience with CMVC in $\mathrm{HIV}^{+}$patients focusing on the endoscopic appearance.

\section{METHOD}

From July 1989 to March 2004, 200 consecutive seropositive patients for human immunodeficiency virus type-1 with at least 3 weeks period of diarrhea underwent

Study conducted on "Hospital Sírio Libanês", São Paulo, SP, Brazil.

Correspondence: Dr. Esdras Camargo A. Zanoni - Rua Prof. Pedro Viriato Parigot de Souza, 2500 - apt. 84A - 81200-100 - Curitiba, PR, Brazil. E-mail: esdras_zanoni@yahoo.com.br 
colonoscopy were retrospectively identified at "Sirio Libanes" Hospital and "Casa da AIDS", São Paulo, SP, Brazil. They were submitted to 243 colonoscopies.

Patients were prepared with oral $10 \%$ manitol solution. The procedures were carried out under sedation with intravenous meperidine and diazepan.

Intubation of the terminal ileum was always tried and achieved in $84.31 \%$ of the cases.

Biopsies were taken from ileum and all colonic segments, regardless endoscopic appearance of mucosa.

Concerning endoscopic findings, an ulcer was defined as a well-defined break into the colonic mucosa in greatest dimension and was assessed in its base by open biopsy forceps. Colitis was endoscopically defined as a loss of the normal vascular pattern added by subepithelial hemorrhage and mucosal friability.

Tissue specimens were fixed in $4 \%$ formalin and paraffin embedded. Sections were stained with hematoxylin-eosin (H-E), acid fast stain and Gomori-Grocott. In doubtful cases as protozoa infestation, Giemsa stain was also performed. They were also processed for immunohistochemical staining through CMV monoclonal antibodies.

\section{RESULTS}

Over 10-year period 243 colonoscopies were performed on $200 \mathrm{HIV}^{+}$patients with diarrhea whom 51 were diagnosed with CMVC. Forty-four of these patients were male and seven were female. The age ranges from 25 to 67 years and the mean age was $37.54 \pm 9$ years.

The cecum was achieved in $98.03 \%$ and ileum intubation was possible in $88.23 \%$ of these 51 patients.

Risk factors for HIV-1 infection included homosexuality $(\mathrm{n}=25,49 \%)$, heterosexuality $(\mathrm{n}=5,9.8 \%)$, drug addiction $(\mathrm{n}=2,3.9 \%)$ and not determined $(\mathrm{n}=19,37.3 \%)$.

All patients were CDC (Center for Disease Control and Prevention classification) stage C. The mean CD4 lymphocyte counts were $127.92 / \mathrm{mm}^{3}$ (range 1 to $646 / \mathrm{mm}^{3}$ ). Fifty-six percent had CD4 lymphocyte counts $<50 / \mathrm{mm}^{3}, 60 \%$ CD4 counts $<100 / \mathrm{mm}^{3}$ and $80 \%$ CD4 counts $<200 / \mathrm{mm}^{3}$.

The main reason for colonoscopy was only diarrhea in 42 $(82.3 \%)$, diarrhea with abdominal pain in $6(11.8 \%)$ and diarrhea with gastrointestinal bleeding in $3(5.9 \%)$ cases.

Endoscopic changes observed in these patients were heterogeneous. The most frequent lesions were ulcers visualized in $37(72.54 \%)$ patients. In $19(37.25 \%)$ patients these ulcers were associated to inflammatory process (Figure 1) and in 18 (35.29\%) were not associated (Figures 2 and 3). An inflammatory process of the mucosa, similar to the observed in mild inespecific ulcerative colitis, was the only detectable change in $11(21.56 \%)$ patients (Figure 4$)$. Three patients $(5.88 \%)$ presented with no endoscopic findings (Table 1).

There were no defined patterns for these ulcers, being some lesions shallow and isolated while others were moderatelly deep and covered with fibrin presenting hyperemic borders. Ulcers with elevated borders (volcano aspect) were also

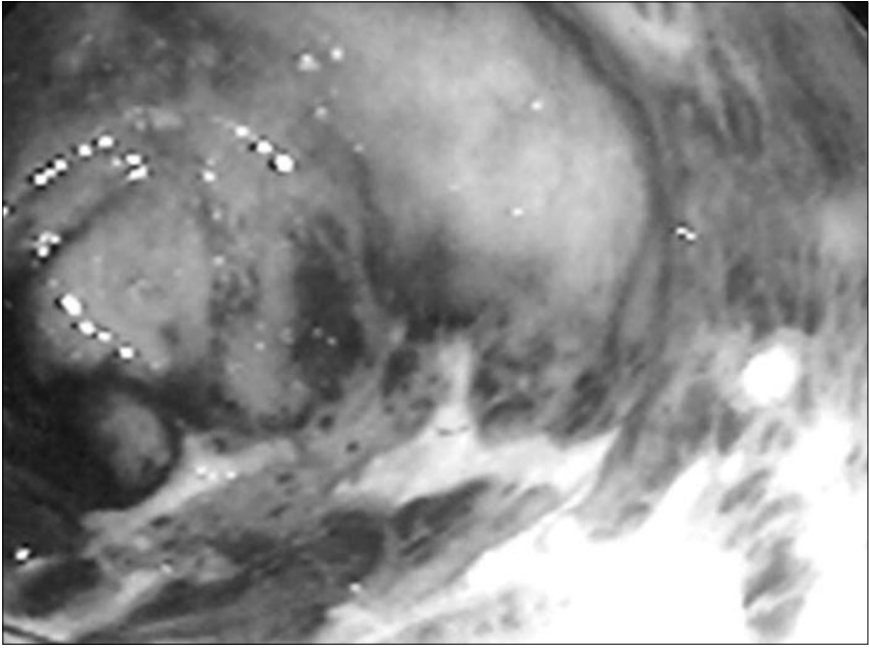

FIGURE 1. Ulcer associated to inflammatory process

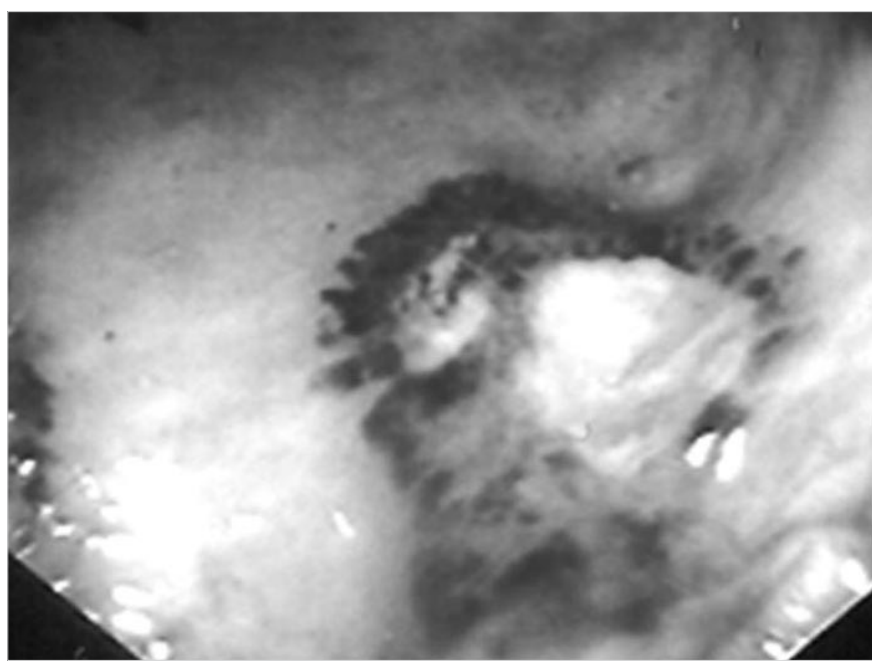

FIGURE 2. Ulcer

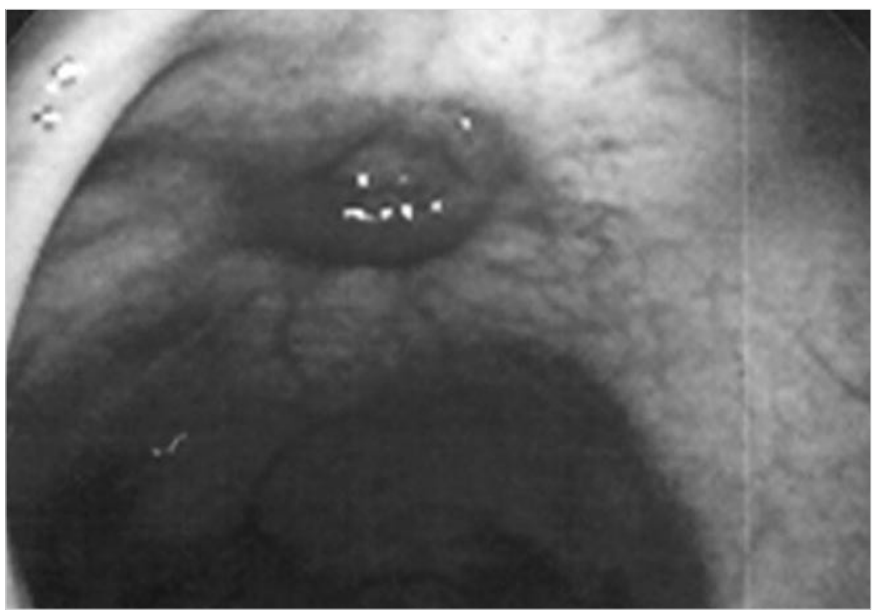

FIGURE 3. Ulcer 
TABLE 1. Endoscopic findings in CMVC

\begin{tabular}{lcc}
\hline Types of mucosal abnormalities & $\mathrm{n}$ & $\%$ \\
\hline Ulcers and inflammation & 19 & 37.25 \\
Ulcers & 18 & 35.29 \\
Inflammation & 11 & 21.56 \\
Normal & 3 & 5.88 \\
Total & 51 & 100 \\
\hline
\end{tabular}

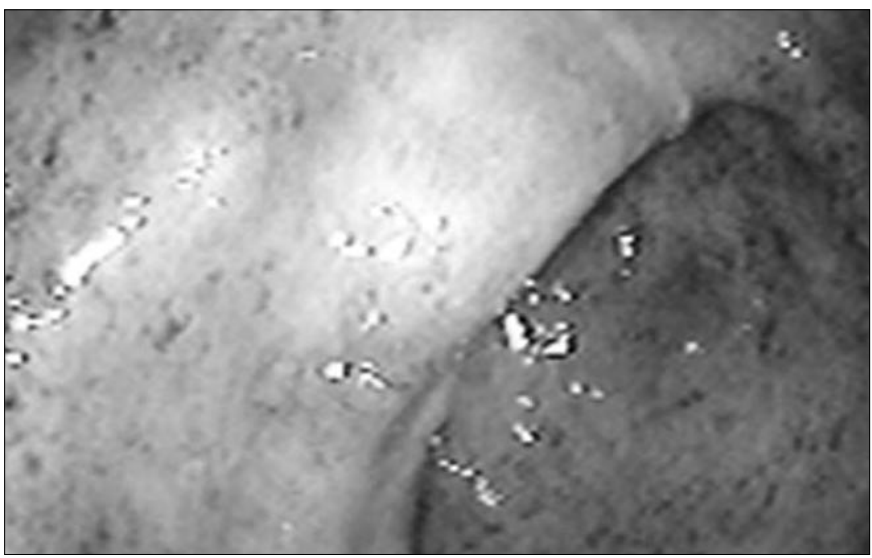

FIGURE 4. Inflammatory process similar to mild ulcerative colitis

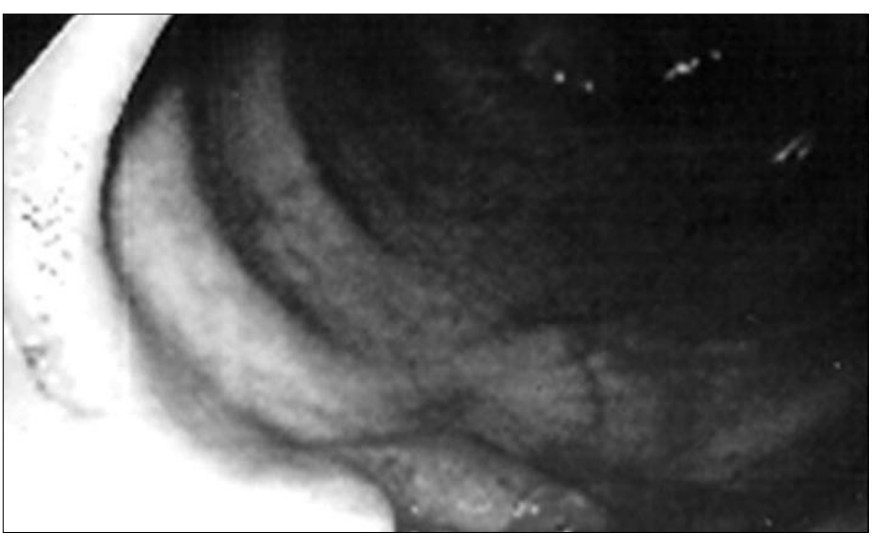

FIGURE 5. Ulcer with elevated borders (volcano aspect)

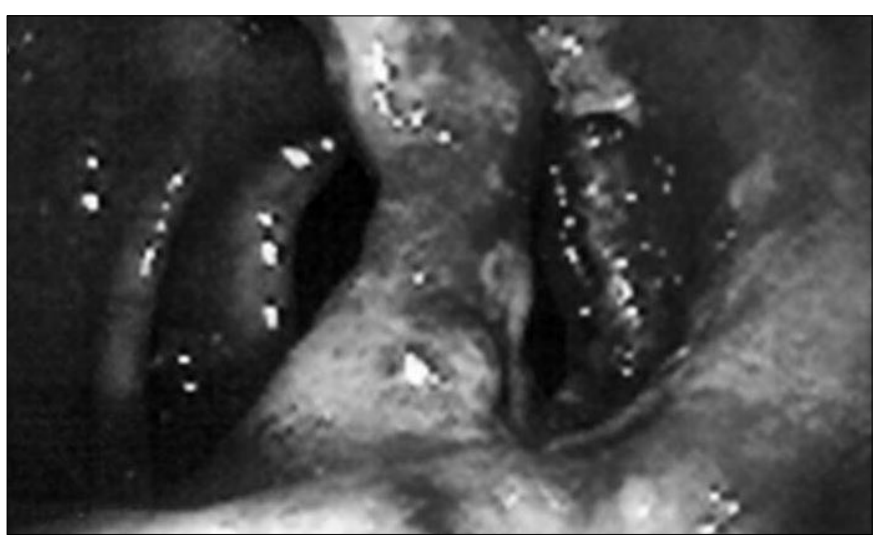

FIGURE 6. Mucosal bridges due to deeper ulcers observed (Figure 5). In some cases there were intramural perforations with formation of mucosal bridges due to deeper ulcers (Figure 6).

Two patients had raised purple erythematous lesions resembling Kaposi's sarcoma but showed characteristic inclusion bodies on histopathology.

Pancolonic mucosal abnormalities were seen in 28 patients $(54.9 \%)$. In $15(29.4 \%)$ the terminal ileum was involved with no predominant pattern. The rectum was attacked in 30 patients $(58.8 \%)$ and segmental involvement of the colon was found in 17 patients $(33.3 \%)$. The rectum and sigmoid colon were spared in $9(17.6 \%)$ (Table 2$)$.

In all cases, CMVC was diagnosed by the identification of nuclear and cytoplasmatic inclusions and confirmed by immunohystochemical reaction using anti-CMV monoclonal antibody (Dakopatts, Denmark).

TABLE 2. Localization of mucosal abnormalities

\begin{tabular}{lccccc}
\hline Localization & $\mathrm{U}+\mathrm{I}$ & $\mathrm{U}$ & $\mathrm{I}$ & Total & $\%$ \\
\hline Rectum / colon / ileum & 6 & 1 & 3 & 10 & $19.6 \%$ \\
Rectum / colon & 6 & 2 & 2 & 10 & $19.6 \%$ \\
Rectum / colon (proximal segment) & 3 & 1 & 0 & 4 & $7.8 \%$ \\
Colon / ileum & 1 & 0 & 0 & 1 & $1.9 \%$ \\
Rectum / ileum & 1 & 0 & 0 & 1 & $1.9 \%$ \\
Rectum / colon (two segments) & 1 & 0 & 0 & 1 & $1.9 \%$ \\
\hline Proximal colon / ileum & 0 & 3 & 0 & 3 & $5.9 \%$ \\
Colon (proximal segment) & 1 & 3 & 2 & 6 & $11.7 \%$ \\
Colon (distal segment) & 0 & 1 & 0 & 1 & $1.9 \%$ \\
Colon (distal segment) / rectum & 0 & 0 & 2 & 2 & $3.9 \%$ \\
Colon & 0 & 7 & 0 & 7 & $13.7 \%$ \\
Rectum & 0 & 0 & 2 & 2 & $3.9 \%$ \\
Normal mucosa & 0 & 0 & 0 & 3 & $5.9 \%$ \\
Total & 19 & 18 & 11 & 51 & $100 \%$ \\
\hline
\end{tabular}

U: ulcers; I: inflammation; $U+1$ : ulcers and inflammation

\section{DISCUSSION}

The high prevalence of CMV infection of gastrointestinal tract in $\mathrm{HIV}^{+}$patients and severity of its symptoms, make diagnosis an important rule. CMV has been one of the pathogens in $45 \%$ of patients presenting with severe diarrhea ${ }^{(33)}$. In a study from MENTEC et al. ${ }^{(28)}$ was showed a prevalence of $13 \%$ in $\mathrm{CMV}$ infection on their $\mathrm{HIV}^{+}$patients with digestive symptoms. In our study we have found a prevalence of $25.5 \%$ in CMV infection on $\mathrm{HIV}^{+}$patients with diarrhea.

Clinical manifestations of CMV infection are not specific ${ }^{(31,22)}$ The frequency of diarrhea has been reported to be as high as $85 \%$ in mucosal cytomegalic inclusion disease and $100 \%$ in $\mathrm{CMVC}^{(12,30)}$ Abdominal pain is present in $46 \%$ to $87.3 \%$ of patients ${ }^{(9,13)}$ CMVC is the most common cause of diarrhea associated with diffuse abdominal pain and that association should therefore raise the index of suspicion for CMVC in a $\mathrm{HIV}^{+}$patient ${ }^{(35)}$

Mucosal abnormalities of the colon were present in 48 (94.1\%) patients and were absent in $3(5.88 \%)$ patients. In a large report of 252 AIDS patients with CMVC, 97.6\% had mucosal abnormalities and $2.4 \%$ had normal mucosal aspect ${ }^{(5)}$ 
Endoscopic findings vary from hyperemia to hemorrhagic erythema including superficial and deep ulcerations of the colon $^{(30)}$ Cytomegaloviral disease can sometimes resembles pseudomembranous colitis or even coexist with it in AIDS patients as well as in transplant receptors. CMV activation can occur due to inflammatory process of the pseudomembranous colitis, just as it can exacerbates inflammatory bowel disease ${ }^{(18,21)}$

Reminiscent violaceous mucosal lesions from Kaposi's sarcoma, but with typical histological features of CMVC have been rarely noted ${ }^{(27,30)}$ and was present in two of our patients.

The distribution of the lesions on intestine in this report was interesting. The rectosigmoid appeared macroscopically normal in nine (17.6\%) of our patients. This finding supports that reported by DIETERICH and RAHMIN ${ }^{(14)}$ who suggested that the reach of flexible sigmoidoscope could misdiagnosis CMVC when it is confined to the proximal colon. BINI et al. ${ }^{(17)}$ also found isolated disease in the proximal colon in $29.3 \%$ of 246 patients. Numerous case reports have shown a considerable number of patients with proximal colonic disease $\mathrm{s}^{(2,3,14,39)}$ It supports our policy of performing colonoscopy instead of flexible sigmoidoscopy in evaluation of $\mathrm{HIV}^{+}$patients with chronic unexplained diarrhea or gastrointestinal bleeding. On the other hand some investigators have found that flexible sigmoidoscopy is an adequate test to make diagnosis of $\mathrm{CMVC}^{(8,11,24,38)}$ Thus, the value of colonoscopy versus flexible sigmoidoscopy in the diagnosis of lower tract infections has not been fully defined and warrants further evaluation.

BINI et al. ${ }^{(17)}$ found statistically significant difference in the distribution of endoscopic appearance of CMVC. In the left colon diffuse mucosal changes with or without ulcers were the most common endoscopic finding. On the other hand, the right colon generally showed isolated ulcers without colitis.

It has also been demonstrated that cells can be infected by CMV even when normal mucosal areas are seen ${ }^{(14,30)}$. It suggests that on evaluation for suspected CMVC, multiple biopsies must be taken throughout the colon, despite of its normal appearance.

\section{CONCLUSION}

Colonoscopy is an important tool to investigate $\mathrm{HIV}^{+}$patients with gastrointestinal symptoms. CMVC must be considered in the diagnosis of these patients and biopsies have always to be attempted even when there is no mucosal abnormalities.

Marques Jr O, Averbach M, Zanoni ECA, Corrêa PAFP, Paccos JL, Cutait R. Colite por citomegalovírus em pacientes HIV positivo: aspectos endoscópicos. Arq Gastroenterol. 2007;44(4):315-9.

RESUMO - Racional - Diarréia em pacientes soropositivos para o vírus da imunodeficiência adquirida é um dos sintomas mais importantes e debilitantes e freqüentemente reduz sua qualidade de vida. Colite por citomegalovírus está entre as principais causas desse sintoma e a colonoscopia é o exame padrãoouro para seu diagnóstico. Objetivo - Definir os principais achados endoscópicos em pacientes $\mathrm{HIV}^{+}$com colite por citomegalovírus. Método - Duzentas e quarenta e três colonoscopias foram realizadas em 200 pacientes $\mathrm{HIV}^{+}$com diarréia associada ou não à dor abdominal ou sangramento gastrointestinal, em período de 10 anos, dos quais 51 pacientes foram diagnosticados com colite por citomegalovírus. Colonoscopia total com entubação ileal foi sempre tentada e múltiplas biopsias de todos os segmentos, incluindo segmentos endoscopicamente normais, foram realizadas. Todos os resultados foram confirmados por estudos histológicos e imunoistoquímicos. Resultados - A colonoscopia total foi possível em $98,03 \%$ e entubação ileal em $88,23 \%$ dos pacientes com colite por citomegalovírus. Nestes pacientes, identificou-se padrão ulcerativo heterogêneo em $72,54 \%$, processo inflamatório da mucosa em $21,56 \%$ e mucosa de aspecto normal em 5,93\% das colonoscopias. Conclusão - Podemos concluir que colonoscopia total com entubação ileal com múltiplas biopsias de todos os segmentos, mesmo quando são endoscopicamente normais, têm que ser sempre realizadas em casos de pacientes $\mathrm{HIV}^{+}$com diarréia.

DESCRITORES - Síndrome da imunodeficiência adquirida. Colite. Infecções por citomegalovírus. Diarréia. Colonoscopia. 


\section{REFERENCES}

1. Beaugerie L, Ngo Y, Goujard F, Gharakhanian S, Carbonnel F, Luboinski J, Malafosse M, Rozenbaum W, Le Quintrec Y. Etiology and management of toxic megacolon in patients with human immunodeficiency virus infection. Gastroenterology. 1994;107:858-63.

2. Bini EJ, Cohen J. Diagnostic yield and cost-effectiveness of endoscopy in chronic human immunodeficiency virus-related diarrhea. Gastrointest Endosc. 1998;48:354-61.

3. Bini EJ, Weinshel EH. Endoscopic evaluation of chronic human immunodeficiency virus-related diarrhea: is colonoscopy superior to flexible sigmoidoscopy? Am J Gastroenterol. 1998;93:56-60.

4. Bini EJ, Weinshel EH, Falkenstein DB. Risk factors for recurrent bleeding and mortality in human immunodeficiency virus-infected patients with acute lower GI hemorrhage. Gastrointest Endosc. 1999;49:748-53

5. Bini EJ, Gorelick SM, Weinshel EH. Outcome of AIDS - associated Cytomegalovirus in the era of potent antiretroviral therapy. J Clin Gastroenterol. 2000;30:414-9.

6. Blanshard C. Treatment of HIV-related cytomegalovirus disease of the gastrointestinal tract with foscarnet. J Acquir Immune Defic Syndr. 1992;5 (suppl 1):s25-s8.

7. Blanshard C, Benhamou Y, Dohin E, Lernestedt JO, Gazzard BG, Katlama C. Treatment of AIDS-associated gastrointestinal cytomegalovirus infection with foscarnet and ganciclovir: a randomized comparison. J Infect Dis. 1995;172:622-8.

8. Blanshard C, Francis N, Gazzard BG. Investigation of chronic diarrhea in acquired immunodeficiency syndrome: a prospective study of 155 patients. Gut. 1996;39:824-32.

9. Chalasani N, Wilcox CM. Etiology and outcome of lower gastrointestinal bleeding in patients with AIDS. Am J Gastroenterol. 1998;93:175-8.

10. Chui DW, Owen RL. AIDS and the gut. J Gastroenterol Hepatol. 1991;9:291-303.

11. Connolly GM, Forbes A, Gleeson JA, Gazzard BG. The value of barium enema and colonoscopy in patients infected with HIV. AIDS. 1990;4:687-9.

12. Culpepper-Morgan JA, Kotler DP, Scholes JV, Tierney AR. Evaluation of diagnostic criteria for mucosal cytomegalic inclusion disease in the acquired immunodeficiency syndrome. Am J Gastroenterol. 1987,82:1264-70.

13. DeRodriguez CV, Fuhrer J, Lake-Bakaar G. Cytomegalovirus colitis in patients with acquired immunodeficiency syndrome. J R Soc Med. 1994;87:203-5.

14. Dieterich DT, Rahmin M. Cytomegalovirus colitis in AIDS: presentation in 44 patients and review of literature. J Acquir Immune Defic Syndr. 1991;4 (suppl 1): s29-35.

15. Dieterich DT, Kim MH, McMeeding A, Rotterdam H. Cytomegalovirus appendicitis in a patient with acquired immunodeficiency syndrome. Am J Gastroenterol. 1991;86:904-6.

16. Dieterich DT, Poles MA, Dicker M, Tepper R, Lew E. Foscarnet treatment of cytomegalovirus gastrointestinal infections in acquired immunodeficiency syndrome patients who have failed ganciclovir induction. Am J Gastroenterol. 1993;88:542-8.

17. Drew WL. Cytomegalovirus infection in patients with AIDS. J Infec Dis. 1988, 158:449-56

18. Franco J, Massey BT, Komorowski R. Cytomegalovirus infection causing pseudomembranous colitis. Am J Gastroenterol. 1994;89:2246-8.

19.. Gallant JE, Moore RD, Richman DD, Keruly J, Chaisson RE, The Zidovudine Epidemiology Study Group. Incidence and natural history of cytomegalovirus disease in patients with advanced human immunodeficiency virus disease treated with zidovudine. J Infect Dis. 1992;166:1223-7.

20. Gazzard B, Blanshard C. Diarrhea in AIDS and other immunodeficiency states. Baillieres Clin Gastroenterol. 1993;7:387-419.

21. Goodgame RW. Gastrointestinal cytomegalovirus diseases. Ann Intern Med 1993;119:924-35

22. Jacobson MA, Mills J. Serious cytomegalovirus disease in the acquired immunodeficiency syndrome (AIDS). Clinical findings, diagnosis and treatment. Ann Intern Med. 1988;108:585-94
23. Jacobson MA, O’Donnell JJ, Porteous D, Brodie HR, Feigal D, Mills J. Retinal and gastrointestinal disease due to cytomegalovirus in patients with the acquired immunodeficiency syndrome: prevalence, natural history, and response to ganciclovir therapy. Q J Med. 1988;67:473-86.

24. Kearney DJ, Steuerwald M, Koch J, Cello JP. A prospective study of endoscopy in HIV-associated diarrhea. Am J Gastroenterol. 1999;94:596-602.

25. Kram HB, Hino ST, Cohen RE, De Santis SA, Shoemaker WC. Spontaneous colonic perforation secondary to cytomegalovirus in a patient with acquired immunodeficiency syndrome. Crit Care Med. 1984;12:469-71.

26. Laughon BE, Druckman DA, Vernon A, Quinn TC, Polk BF, Modlin JF, Yolken RH, Bartlett JG. Prevalence of enteric pathogens in homosexual men with and withou acquired immunodeficiency syndrome. Gastroenterology. 1988;94:984-93.

27. Meiselman MS, Cello JP. Cytomegalovirus colitis. Report of the clinical, endoscopic and pathological findings in two patients with the acquired immunodeficiency syndrome. Gastroenterology. 1985;88:171-5.

38. Mentec H, Lepot C, Leport J, Marche C, Haarzic and Vildé JL. Cytomegalovirus colitis in HIV 1 infected patients: a prospective research in 55 patients. AIDS 1994;8:461-7.

39. Olofindale $\mathrm{O}$, Chiang $\mathrm{C}$. Cytomegalovirus infection as a cause of pseudomembranous colitis: a report of four cases. J Clin Gastroenterol. 2001;32:82-4.

30. Rene E, Marche C, Chevalier T, Rouzioux C, Regnier B, Saimot AG, Negesse Y, Matheron S, Leport C, Wolff B. Cytomegalovirus colitis in patients with acquired immunodeficiency syndrome. Dig Dis Sci. 1988;33:741-50.

31. Rene E, Marche C, Régnier B, Saimot AG, Vilde JL, Perrone C, Michon C, Wolf $\mathrm{M}$, Chevalier T, Vallot T. Intestinal infections in patients with acquired immunodeficiency syndrome. A prospective study in 132 patients. Dig Dis Sci. 1989;34:773-80

32. Smallwood RA. AIDS and the gastroenterologist. J Gastroenterol Hepatol. 1990;5 (suppl 1):45-61.

33. Smith PD, Lane HC, Gill VJ, Manischewitz JF, Quinnan GV, Fauci AS, Masur H Intestinal infection in patient with acquired immunodeficiency syndrome: etiology and response to therapy. Ann Intern Med. 1988;108:328-33.

34. Tatum ET, Sun PC, Cohn DL. Cytomegalovirus vasculitis and colon perforation in a patient with the acquired immunodeficiency syndrome. Pathology. 1989;21:235-8.

35. Thuluvath PJ, Connolly GM, Forbes A, Gazzard BG. Abdominal pain in HIV infection. Q J Med. 1991;78:275-85.

36. Torres HA, Kontoyiannis DP, Bodey GP, Adachi JA, Luna MA, Tarrand JJ, Noguera GM, Raad II, Chemaly RF. Gastrointestinal cytomegalovirus disease in patients with cancer: a two decade experience in a tertiary care cancer center. Eur J Cancer. 2005;41:2268-79.

47. Wei SC, Hung CC, Chen MY, Wasng CY, Chuang CY, Wong JM. Endoscopy in acquired immunodeficiency syndrome patients with diarrhea and negative stool studies. Gastrointest Endosc. 2000;51:427-32.

48. Wilcox CM, Swartz DA, Cotsonis G, Thompson SE. Chronic unexplained diarrhea in human immunodeficiency virus infection: determination of the best diagnostic approach. Gastroenterology. 1996;110:30-7.

49. Wilcox CM, Chalasani N, Lazenby A, Schwartz DA. Cytomegalovirus colitis in acquired immunodeficiency syndrome: a clinical and endoscopic study. Gastrointest Endosc. 1998;48:39-43.

40. Wisser J, Zingman B, Wasik M, Duva-Frissora A, Beazley R, McAneny D Cytomegalovirus pseudotumor presenting as bowel obstruction in a patient with acquired immunodeficiency syndrome. Am J Gastroenterol. 1992;87:771-4

Recebido em 26/3/2007 Aprovado em 12/7/2007 